\title{
Effect of Bacteriophage C5 on Ultraviolet Light Survival in Pseudomonas aeruginosa
}

\author{
By C. D. DIRCKZE, P. R. LEHRBACH AND B. T. O. LEE \\ Department of Genetics, University of Melbourne, Parkville, Victoria 3052, \\ Australia
}

(Received 7 November 1978)

Bacteriophage $\mathrm{C} 5$ of Pseudomonas aeruginosa is able to reactivate ultraviolet (u.v.)-irradiated phage E79 in coinfection experiments and decrease the u.v.-sensitivity of a host-cell reactivation deficient mutant. These properties suggest that phage $\mathrm{C} 5$ has a gene(s) which is involved in the repair of u.v.-damaged DNA. The isolation of two u.v.-sensitive mutants of C5 supports this hypothesis.

\section{INTRODUCTION}

The survival of a bacteriophage following ultraviolet (u.v.) irradiation is mainly dependent on the capacity of the host cell systems that repair the u.v.-damaged DNA. Some bacteriophages, however, are able to repair u.v.-induced damage by a phage-coded enzymic dark repair system. In the case of the Escherichia coli bacteriophage T4, at least three bacteriophage-coded genes $-v$ (Harm, 1963), $x$ (Harm, 1963) and $y$ (Boyle \& Symonds, 1969) - have been implicated in the repair of u.v.-damaged DNA. The $v$-gene codes for an endonuclease which carries out the incision step of excision repair (Yasuda \& Sekiguchi, 1970; Friedberg $\&$ King, 1971). Furthermore, Harm (1968) has shown that the $v$-gene product does not discriminate between bacterial and phage DNA so that the u.v.-survival of $E$. coli strain $\mathrm{B}_{\mathrm{s}-1}$ can be significantly increased following infection with heavily irradiated T4.

In this report we describe some properties of the Pseudomonas aeruginosa bacteriophage $\mathrm{C} 5$ (Bradley \& Pitt, 1974) which affect the repair of u.v. damage in bacteriophage and bacterial DNA.

\section{METHODS}

Media and general culture procedures. These techniques have been described previously (Kung \& Lee, 1973). Layer agar for bacteriophage assays was Bresch layer agar containing $1 \%(\mathrm{w} / \mathrm{v})$ Bacto-tryptone, $0.5 \%(\mathrm{w} / \mathrm{v})$ yeast extract, $0.05 \%(\mathrm{w} / \mathrm{v}) \mathrm{NaCl}$ and solidified with $1.0 \%(\mathrm{w} / \mathrm{v})$ agar.

Bacterial and bacteriophage strains. The standard wild-type strain is Pseudomonas aeruginosa PAO1 (ATCC 15692) (Holloway, 1955). Strain GMA918 was derived from PAO1 (Kung \& Lee, 1973) by $N$-methyl$N^{\prime}$-nitro- $N$-nitrosoguanidine (NTG) mutagenesis and shows increased sensitivity to u.v. light and reduced ability to reactivate u.v.-treated phage E79; it is a selected member of phenotypic class 9 (Kung \& Lee, 1973) and is considered to be a host-cell reactivation (hcr) mutant. Strain GMC161 was isolated by the method of Kropinski ct al. (1977) as a spontaneous C5-resistant, E79-sensitive mutant of GMA918 and was used in coinfection experiments.

Bacteriophage $\mathrm{C} 5$ has been described by Bradley \& Pitt (1974) and was obtained from G. A. Jacoby. Bacteriophage E79 has been described by Holloway et al. (1960).

Host-cell reactivation (hcr) experiments. In hor experiments, a Tris/sodium/magnesium buffer (TNM) (Kung \& Lee, 1973) suspension of the phage was exposed to various doses of u.v.-irradiation as previously described (Kung \& Lee, 1973). The irradiated phage was then diluted and assayed on the appropriate test strains.

Recovery of u.v.-irradiated E79 by coinfection with heavily irradiated $\mathrm{C} 5$. An overnight $\left(16 \mathrm{~h}\right.$ at $\left.37^{\circ} \mathrm{C}\right)$ 


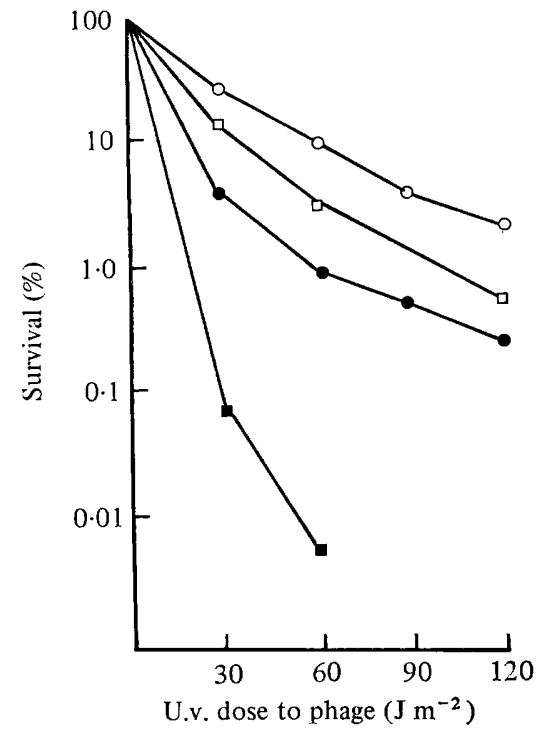

Fig. 1

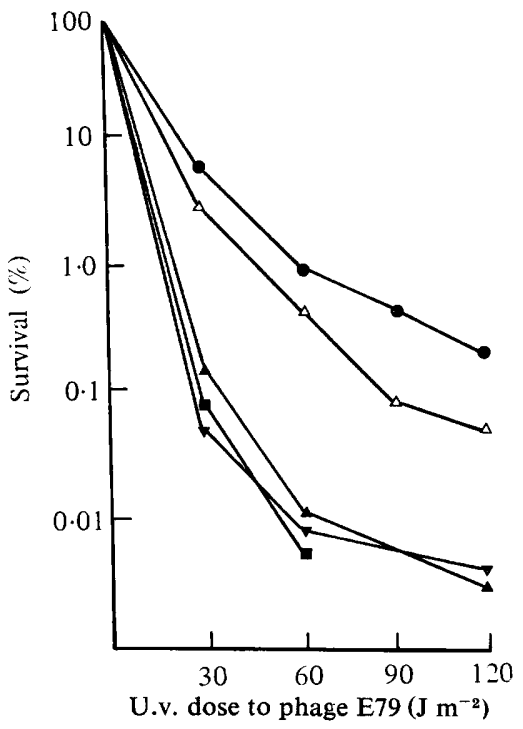

Fig. 2

Fig. 1. Host-cell reactivation of u.v.-irradiated phage E79 $(\square, \bigcirc)$ and phage $C 5(\square, \bigcirc)$ on strains: 口, $\square$, GMA918;, , PAO1.

Fig. 2. Host-cell reactivation of u.v.-irradiated phage E79 on strains: O, PAO1; $\mathbf{0}$, GMA918; $\triangle$, GMA918 plus heavily u.v.-irradiated phage C5 $\left(200 \mathrm{~J} \mathrm{~m}^{-2}\right.$, survival 1 in $10^{8}$, m.o.i. 5 to 10$)$; $\Delta$, GMA918 plus heavily u.v.-irradiated mutant phage $\mathrm{C} 5(101)\left(180 \mathrm{~J} \mathrm{~m}^{-2}\right.$, survival 1 in $10^{8}$, m.o.i. 5 to 10$) ; \nabla$, GMA918 plus heavily u.v.-irradiated mutant phage C5(102) $\left(180 \mathrm{~J} \mathrm{~m}^{-2}\right.$, survival 1 in $10^{8}$, m.o.i. 5 to 10 ).

shaken broth culture of strain GMA918 was infected with phage E79, exposed to various doses of u.v. light, at a multiplicity of infection (m.o.i.) of 1 and coinfected with heavily u.v.-irradiated $\left(200 \mathrm{~J} \mathrm{~m}^{-2}\right)$ bacteriophage C5 (survival 1 in $10^{8}$; m.o.i. 5 to 10). After $10 \mathrm{~min}$ incubation at $37^{\circ} \mathrm{C}$, to allow for phage adsorption, the cells were diluted and the survival of E79 was assayed on GMC161. Control experiments were performed in a similar manner, using the same suspension of phage E79 (m.o.i. 1) but no bacteriophage C5 was added.

U.v.-survival of GMA918 following infection with heavily irradiated C5. TNM buffer suspensions of GMA918 were exposed to various doses of u.v. light and immediately infected with heavily u.v.-irradiated $\left(200 \mathrm{~J} \mathrm{~m}^{-2}\right.$ ) bacteriophage $\mathrm{C} 5$ (survival 1 in $10^{8}$; m.o.i. 5 to 10 ). After $10 \mathrm{~min}$ incubation at $37^{\circ} \mathrm{C}$, the cells were diluted and assayed for survival on nutrient agar. Plates were incubated overnight at $37^{\circ} \mathrm{C}$ before colony counts were made.

Bacteriophage mutagenesis. This procedure was used to isolate u.v.-sensitive mutants of phage C5. An overnight $\left(16 \mathrm{~h}\right.$ at $\left.37^{\circ} \mathrm{C}\right)$ shaken broth culture was centrifuged and resuspended in $1 \mathrm{ml}$ citrate buffer (pH $5 \cdot 8)$ and an equal volume of phage C5 (m.o.i. 1) was added. Immediately, NTG $\left(100 \mu \mathrm{g} \mathrm{ml}^{-1}\right)$ was added and the suspension was incubated at $37^{\circ} \mathrm{C}$ without shaking for $60 \mathrm{~min}$. A sample was then withdrawn, diluted and plated on PAO1 to obtain C5 plaques. Individual plaques were picked and phage particles were suspended in $0.5 \mathrm{ml}$ TNM buffer. Control and u.v.-irradiated phage were replica-plated on to prepared lawns of PAO1 and GMA918. Phage isolates showing increased sensitivity when plated on GMA918 but normal plating on PAO1 were further tested and characterized. Two u.v.-sensitive mutants of C5 designated by the strain numbers C5(101) and C5(102) were isolated.

\section{RESULTS AND DISCUSSION}

The survival of u.v.-irradiated phage C5 and E79 plated on host cells PAO1 (wild-type for repair) and a her mutant GMA918 are shown in Fig. 1. As previously described (Kung \& Lee, 1973), GMA918 showed a greatly reduced ability to host-cell reactivate (hcr) u.v.irradiated phage E79 compared with PAO1. This difference in her capacity was not shown for phage $\mathrm{C} 5$ where there was only a slight difference in the u.v.-survival curves on PAO1 and GMA918. The different u.v.-survival of phages C5 and E79 on GMA918 could be due to the 


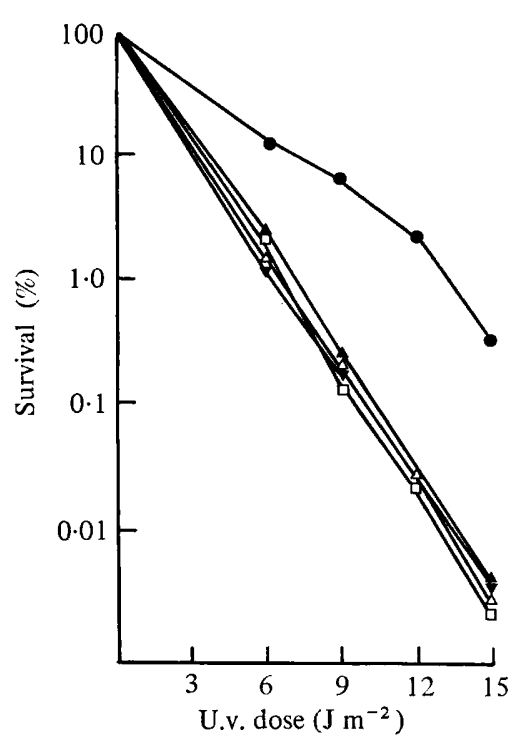

Fig. 3

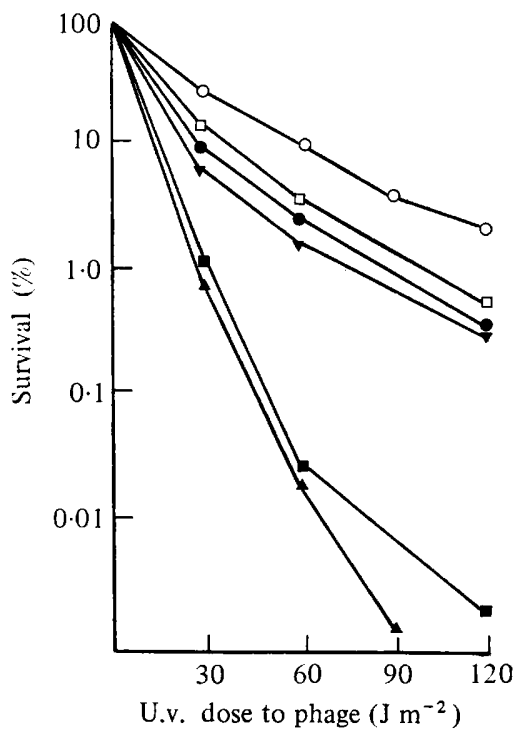

Fig. 4

Fig. 3. U.v.-survival of strain GMA918 following infection with heavily u.v.-irradiated phage: C5; $\Delta$, C5(101); $\nabla$, C5(102); $\triangle$, E79; $\square$, no phage added.

Fig. 4. Host-cell reactivation of u.v.-irradiated phage C5 $(O, \square), \operatorname{C5}(101)(\boldsymbol{\nabla}, \Delta)$ and C5 (102) $(\boldsymbol{O}, \boldsymbol{\square})$ on strains: $\bigcirc, \boldsymbol{\nabla}, \boldsymbol{\nabla}$, PAO1; $\square, \boldsymbol{\Delta}, \mathbf{\square}$, GMA918.

presence of phage-determined gene(s) in phage $\mathrm{C} 5$ which partially compensate for the repair deficiency of GMA918. To test this hypothesis, the survival of u.v.-irradiated phage E79 on both PAO1 and GMA918 as well as the u.v.-survival of GMA918 following infection with heavily u.v.-irradiated phage C5 was determined.

The survival of u.v.-irradiated phage E79 infecting GMA918 simultaneously infected with heavily u.v.-irradiated phage C5 (m.o.i. 5 to 10), the survival of u.v.-irradiated phage C5 singly infecting GMA918 and the survival of u.v.-irradiated phage E79 singly infecting GMA918 were determined (Fig. 2). The u.v.-survival of phage E79 in these experiments was determined on strain GMC161. The results show that simultaneous infection with heavily u.v.-irradiated $\mathrm{C} 5$ is able to increase the survival of u.v.-irradiated phage E79. Further evidence for the hypothesis that phage $\mathrm{C} 5$ determines a gene product(s) which may participate in the repair of u.v.-damaged DNA was obtained by determining the u.v.-survival of GMA918 infected with heavily u.v.-irradiated phage C5 (Fig. 3). Phage C5 considerably affects the survival of GMA918 at the u.v. doses tested, whereas infection with heavily u.v.-irradiated $\left(180 \mathrm{~J} \mathrm{~m}^{-2}\right.$ ) phage E79 (survival 1 in $10^{8}$; m.o.i. 5 to 10 ) had no effect on the u.v.-survival of GMA918. Therefore it seems likely that a gene product(s) determined by the phage C5 genome is able to modify the u.v.-survival of phage E79 on a her mutant and the u.v.-survival of GMA918; furthermore, such a phage function does not appear to be present in the phage E79 genome. The isolation of two u.v.-sensitive mutants of phage $\mathrm{C} 5$ provides further evidence that phage $\mathrm{C} 5$ contributes a gene product or products that participate in the repair of u.v.-damaged DNA. These mutant strains C5(101) and C5(102) showed increased u.v.-sensitivity when plated on GMA918 and to a lesser degree on PAO1 (Fig. 4). Furthermore, these mutants do not modify the u.v.-survival of u.v.-irradiated phage E79 (Fig. 2). Therefore phage C5 appears to have similar properties to the u.v.-resistant $E$. coli phage T4 which is able, under appropriate conditions, to increase the u.v.-survival of u.v.-irradiated phage T2 (Harm, 1961) and to effect the recovery of the u.v.-sensitive $E$. coli strain $\mathrm{B}_{\mathrm{s}-1}$ (Harm, 1968) following u.v.-irradiation. 
Further studies will be initiated to define the mode of action of $\mathrm{C} 5$ gene(s) in the repair of u.v.-damaged DNA, its expression and the phage gene product(s) involved.

This work was supported by a Research and Training grant from the Australian Institute of Nuclear Science and Engineering.

\section{REFERENCES}

Boyle, J. M. \& SYmonds, N. (1969). Radiationsensitive mutants of T4D I T4Y : a new radiationsensitive mutant; effect of the mutation on radiation survival, growth and recombination. Mutation Research 8, 431-439.

Bradley, D. E. \& Pitt, T. L. (1974). Pilus-dependence of four Pseudomonas aeruginosa bacteriophages with non-contractile tails. Journal of General Virology 24, 1-15.

FriedberG, E. C. \& KING, J. J. (1971). Dark repair of ultraviolet-irradiated deoxyribonucleic acid by bacteriophage T4: purification and characterization of a dimer specific phage-induced endonuclease. Journal of Bacteriology 106, 500-507.

HARM, W. (1961). Gene-controlled reactivation of ultraviolet-inactivated bacteriophage. Journal of Cellular and Comparative Physiology 58, supp. 1, 69-77.

HARM, W. (1963). Mutants of phage T4 with increased sensitivity to ultraviolet. Virology 19, 66-71.

HARM, W. (1968). Recovery of uv-inactivated E. coli cells by the $v$-gene action of phage T4. Mutation Research 6, 175-179.
Holloway, B. W. (1955). Genetic recombination in Pseudomonas aeruginosa. Journal of General Microbiology 13, 572-581.

Holloway, B. W., EgaN, J. B. \& Monk, M. (1960). Lysogeny in Pseudomonas aeruginosa. Australian Journal of Experimental Biology and Medical Science 38, 321-330.

Kropinski, A. M., Chan, L., Jarrell, K. \& Milazzo, F. H. (1977). The nature of Pseudomonas aeruginosa strain PAO bacteriophage receptors. Canadian Journal of Microbiology 23, 653-658.

Kung, A. H. C. \& LeE, B. T. O. (1973). The isolation and survival characterization of radiation and chemical-mutagen sensitive mutants of Pseudomonas aeruginosa. Mutation Research 20, 175-190.

Yasuda, S. \& SEKIGUChI, M. (1970). Mechanism of repair of DNA in bacteriophage. II. Inability of ultraviolet-sensitive strains of bacteriophage in inducing an enzyme activity to excise pyrimidine dimers. Journal of Molecular Biology 47, 243-255. 